\title{
Mulches enhanced growth and yield of onion
}

\author{
M. G. Rachel ${ }^{1}$, M. M. A. Mondal ${ }^{2 *}$, M. H. R. Pramanik ${ }^{1}$ and M. A. Awal ${ }^{1}$ \\ ${ }^{I}$ Department of Crop Botany, Bangladesh Agricultural University, Mymensingh-2202, Bangladesh \\ ${ }^{2}$ Crop Physiology Division, Bangladesh Institute of Nuclear Agriculture, Mymensingh-2202, Bangladesh
}

\begin{abstract}
Received: 10 October 2017

Revised: 04 February 2018

Accepted: 23 May 2018

The experiment was conducted to investigate the effect of mulches on soil nutrients and microclimate status, growth and bulb yield of onion $c v$. Taherpuri. The experiment was comprised of six mulches viz., i) Control (no mulch), ii) Black polythene sheet, iii) White polythene sheet, iv) Rice straw, v) Water hyacinth and vi) Saw dust. Application of different mulches improved soil microclimates, increased plant growth and bulb yield over control. Among the mulches, black polythene mulch showed superiority in growth and yield contributing characters compared to other mulches, resulting the highest bulb yield.
\end{abstract}

DOI: http://dx.doi.org/10.3329/bjsir.v53i4.39195
Keywords: Mulch; Soil micro-climate; Growth; Yield; Onion

\section{Introduction}

Onion (Allium cepa L.) is by far the most important of the bulb crops and is one of the important popular vegetable crops in the world (FAO, 2016). But in Bangladesh, it is extensively used as a spice for cooking purposes. An edible portion of $100 \mathrm{~g}$ onion bulb contains $1.4 \mathrm{~g}$ protein, $11.2 \mathrm{~g}$ carbohydrate, $12 \mathrm{mg}$ ascorbic acid, $32 \mathrm{mg}$ calcium and 49 calories (Encyclopedia, 2017). Recently, research has suggested that onions in the diet play a vital role in preventing heart diseases and other ailments (Encyclopedia, 2017). Onion is known to contain substances having antibiotic properties. Among the spices grown in Bangladesh, onion ranks second in respect of production and area (MOA, 2016). With the increase of population, the demand as well as the import of onion is increasing day by day. But due to limitation of land it is not possible to raise the production of the crop horizontally. The expansion of onion cultivation will hamper the cultivation of other profitable crops particularly rice, the staple food grain of Bangladesh. The only way to solve the problem is to increase per hectare yield. The average yield per hectare is about 6.82 tons which is much lower than other developed countries where average production is over $17.5 \mathrm{t} \mathrm{ha}^{-1}(\mathrm{FAO}, 2016)$.

Successful onion cultivation largely depends on the optimum cultural management practices. This includes judicious application of manures and fertilizers, efficient use of available soil moisture, spacing and time of planting. Out of these, efficient use of soil moisture is very important, because rainfall is scanty during Rabi season in Bangladesh when farmers grow this valued crop. Onions are rather sensitive to drought stress (Zayton, 2007). One single most important factor that influences seed yield is soil moisture therefore, onions require frequent irrigations. The crop requires $350-500 \mathrm{~mm}$ of water over the growing season (FAO, 2013) hence adequate moisture possibly through irrigation is important in the production of onions. Onion root system is shallow so it extracts very little water from depths beyond 60 $\mathrm{cm}$. Further, growers have to depend either on natural precipitation or supplemental irrigation for growing onion. On the other hand, irrigation feasibilities are not sufficient in all the regions of the country. Sometimes pump cannot lift water in dry season due to lowering of water layer. As a result, the production of onion is hampered to a great extent. Soil moisture is lost through two main processes: i) Evaporation from soil; and ii) Transpiration through plant leaves. Conservation of soil moisture may help in preventing the loss of water through evaporation permitting maximum utilization of moisture by plants. 
Mulching is an important technology which decreases the loss of soil water through evaporation and conserve soil moisture thus reduces the irrigation requirements, increasing root development, promoting faster crop development, reducing weed attack and inducing earlier harvest of crop (Mahajan et al., 2007). In soil management relationships, mulch has been reported to influence organic matter content, activity of microorganisms, availability of soil nutrients, control of erosion and soil compaction and regulating soil temperature (Stowell, 2000). These results suggest that mulch improves the soil environment for increasing crop growth, development and yield

However, onion growth and development is greatly influenced by mulching and irrigation (Rahman et al., 2013). Rhee et al. (1990) showed that mulch increases the efficiency of applied $\mathrm{N}$ fertilizer by reducing leaching and evaporation loss of nutrients. Use of various mulches like black polythene, transparent polythene, rice straw, saw dust, water hyacinth reported to conserve soil moisture efficiently in garlic and onion as reported by many workers (Jamil et al., 2005; Anisuzzaman et al., 2009; Islam et al., 2010; Inusah et al., 2013). Again, Islam et al. (2002) reported that different types of mulches including rice straw and polythene significantly increased the growth and yield of onion. Under these circumstances mulching is an effective cultural practice to ensure crop production especially in dry season. It also helps in better utilization of all the nutrients in the soil (Streck et al., 1995). In view of the above facts, the present study was undertaken to evaluate the changes in temperature and soil moisture and to evaluate the growth and yield of onion under sub-tropical conditions grown with plastic and indigenous natural mulches.

\section{Materials and methods}

The experiment was carried out at the Field Laboratory, Department of Crop Botany, Bangladesh Agricultural University, Mymensingh, during the period from December 2014 to April 2015. The popular onion variety, Taherpuri was used as planting material in the experiment. The experiment consists of five different mulches. These are i) Black polythene sheet, ii) White polythene, iii) Rice straw, iv) Water hyacinth and v) Saw dust along with control (no mulch). The experiment was laid out in a Randomized Complete Block Design where each treatment replicated thrice. The size of the unit plot was $3 \mathrm{~m} \times 2 \mathrm{~m}$. Distance between plant to plant was $10 \mathrm{~cm}$ and row to row was $20 \mathrm{~cm}$. Urea (180 kg ha-1), triple super phosphate $\left.\left(200 \mathrm{~kg} \mathrm{ha}^{-1}\right)\right)$, muriate of potash $\left.\left(170 \mathrm{~kg} \mathrm{ha}^{-1}\right)\right)$ and gypsum $\left(120 \mathrm{~kg} \mathrm{ha}^{-1}\right)$ were used as source of nitrogen, phosphorus, potassium and sulphur, respectively. Well decomposed cowdung $(5000 \mathrm{~kg}$ $\mathrm{ha}^{-1}$ ) was also applied to the field before final land preparation. Thirty five day old healthy and uniform seedlings of onion were transplanted in the afternoon on 10 January 2015. The different mulches were placed on the respective plots as per treatment at 15 DAT with minimum injury to the plants. To study ontogenetic growth characteristics, a total of five harvests were made and at final harvest, data were collected on some morphological, yield attributes and yield. The first crop sampling was done at 40 days after transplanting (DAT) and continued at an interval of 10 days up to 80 DAT. The growth analyses like absolute growth rate and relative growth rate was carried out following the formulae of Hunt (1978). The variation of soil moisture at different growth stages of the crop for different mulched plots was estimated by Gravimetric method. Soil temperature was measured using metal cased soil thermometer. The diurnal fluctuation of soil temperature as influenced by different mulches was measured at $5 \mathrm{~cm}$ depth in three hours intervals from 8.00 am to 5.00 pm on 15 February, 2015. At harvest, 10 plants were randomly selected from each plot for collecting morphological and yield contributing characters. Soil fertility status was analyzed by Hunter (1984) method. The collected data were analyzed statistically.

\section{Results and discussion}

\section{Effect of mulching on soil moisture and temperature}

The effect of different mulching on soil moisture percentage and soil temperature at different growth stages was significant (Tables I and II). Results indicated that soil moisture

percentage and soil temperature was greater in mulches plot than non-mulch plot. Among the mulches, soil moisture and temperature was higher in polythene mulches than the other natural mulches. Result revealed that soil moisture decreased with time in all treatments but the decrement was lower in mulch plot than control plot. The highest soil moisture percentage and soil temperature at all growth stages was recorded in black polythene mulch followed by white polythene mulch with same statistical rank. It means water preservation capacity was higher in black and white polythene mulches than the other mulches. In contrast, the lowest soil moisture and temperature was recorded in control plot. Results showed that soil temperature was low in the morning, which increased with advancement of the day and peak at $15.00 \mathrm{pm}$ followed by a decline in all the treatments. Among the mulches, the soil temperature variation was remarkably low in saw dust mulched plots. In contrast, control plots maintained the lowest soil moisture and temperature. The polythene mulches retained comparatively higher temperature than the others might be due to generating 
Table I. Effect of different mulches on soil moisture content at 0-10 $\mathrm{cm}$ depth in soil at different days after planting

\begin{tabular}{lllll}
\hline & \multicolumn{4}{c}{ Soil moisture content at different days after planting } \\
\cline { 2 - 5 } Mulching treatment & 50 DAT & $60 \mathrm{DAT}$ & $70 \mathrm{DAT}$ & $80 \mathrm{DAT}$ \\
\hline Black polythene & $23.2 \mathrm{a}$ & $22.9 \mathrm{a}$ & $21.6 \mathrm{a}$ & $20.7 \mathrm{a}$ \\
White polythene & $23.1 \mathrm{a}$ & $22.0 \mathrm{a}$ & $20.7 \mathrm{~b}$ & $20.2 \mathrm{a}$ \\
Water hyacinth & $22.6 \mathrm{ab}$ & $21.0 \mathrm{ab}$ & $20.5 \mathrm{~b}$ & $19.8 \mathrm{ab}$ \\
Rice straw & $21.1 \mathrm{bc}$ & $19.6 \mathrm{bc}$ & $19.0 \mathrm{c}$ & $18.3 \mathrm{~b}$ \\
Saw dust & $19.8 \mathrm{~cd}$ & $19.0 \mathrm{~cd}$ & $18.6 \mathrm{~cd}$ & $18.1 \mathrm{~b}$ \\
Control & $19.2 \mathrm{~d}$ & $18.6 \mathrm{~d}$ & $17.4 \mathrm{~d}$ & $16.2 \mathrm{c}$ \\
\hline CV $(\%)$ & 2.81 & 4.13 & 2.63 & 2.86 \\
\hline
\end{tabular}

In a column, figures bearing same letter (s) do not differ significantly at $\mathrm{P} \leq 0.05$ by DMRT

Table II. Diurnal variation of soil temperature at $5 \mathrm{~cm}$ depth in a sunny day on onion plots covered with different mulches on 15 February 2015

\begin{tabular}{llccc}
\hline & \multicolumn{4}{c}{ Soil temperature $\left({ }^{\circ} \mathrm{C}\right)$ at different hours of the day } \\
\cline { 2 - 5 } Mulching treatment & $9 \mathrm{AM}$ & 12 Noon & $15 \mathrm{PM}$ & $18 \mathrm{PM}$ \\
\hline Black polythene & $22.7 \mathrm{a}$ & $30.2 \mathrm{~b}$ & $32.8 \mathrm{a}$ & $29.0 \mathrm{a}$ \\
White polythene & $22.3 \mathrm{a}$ & $32.1 \mathrm{a}$ & $33.4 \mathrm{a}$ & $28.3 \mathrm{ab}$ \\
Water hyacinth & $21.5 \mathrm{~b}$ & $29.0 \mathrm{c}$ & $30.5 \mathrm{~b}$ & $27.5 \mathrm{bc}$ \\
Rice straw & $21.6 \mathrm{~b}$ & $29.2 \mathrm{c}$ & $30.5 \mathrm{~b}$ & $27.4 \mathrm{bc}$ \\
Saw dust & $21.2 \mathrm{bc}$ & $28.3 \mathrm{~d}$ & $29.6 \mathrm{~b}$ & $26.8 \mathrm{c}$ \\
Control & $20.5 \mathrm{c}$ & $27.9 \mathrm{~d}$ & $27.4 \mathrm{c}$ & $25.2 \mathrm{~d}$ \\
\hline CV $(\%)$ & 2.50 & 3.10 & 2.87 & 3.20 \\
\hline
\end{tabular}

Values with same letter (s) in a column do not differ significantly at $\mathrm{P} \leq 0.05$ by DMRT

Table. III. Effect of different mulches on morphological characters, bulb yield and yield attributes in onion

\begin{tabular}{lllllll}
\hline $\begin{array}{l}\text { Mulching } \\
\text { treatment }\end{array}$ & $\begin{array}{l}\text { Plant } \\
\text { height }(\mathrm{cm})\end{array}$ & $\begin{array}{l}\text { Leaves } \\
\text { plant }^{-1}(\text { no. })\end{array}$ & $\begin{array}{l}\text { Leaf length } \\
(\mathrm{cm})\end{array}$ & $\begin{array}{l}\text { Bulb } \\
\text { diameter }(\mathrm{cm})\end{array}$ & $\begin{array}{l}\text { Single bulb } \\
\text { weight }(\mathrm{g})\end{array}$ & $\begin{array}{l}\text { Bulb yield } \\
\left.(\mathrm{t} \mathrm{ha})^{-1}\right)\end{array}$ \\
\hline Black polythene & $40.6 \mathrm{a}$ & $7.25 \mathrm{a}$ & $33.9 \mathrm{a}$ & $4.42 \mathrm{a}$ & $22.0 \mathrm{a}$ & $10.7 \mathrm{a}$ \\
White polythene & $38.2 \mathrm{~b}$ & $6.30 \mathrm{~b}$ & $31.4 \mathrm{ab}$ & $3.96 \mathrm{~b}$ & $17.5 \mathrm{c}$ & $8.86 \mathrm{bc}$ \\
Water hyacinth & $39.4 \mathrm{ab}$ & $6.00 \mathrm{~b}$ & $29.9 \mathrm{bc}$ & $4.12 \mathrm{~b}$ & $20.0 \mathrm{~b}$ & $9.51 \mathrm{ab}$ \\
Rice straw & $35.5 \mathrm{~cd}$ & $5.20 \mathrm{bc}$ & $28.5 \mathrm{bc}$ & $3.80 \mathrm{~b}$ & $16.1 \mathrm{~cd}$ & $8.50 \mathrm{~cd}$ \\
Saw dust & $33.3 \mathrm{~d}$ & $5.00 \mathrm{bc}$ & $27.0 \mathrm{~cd}$ & $3.35 \mathrm{c}$ & $15.4 \mathrm{~d}$ & $7.61 \mathrm{de}$ \\
Control & $30.1 \mathrm{e}$ & $4.50 \mathrm{c}$ & $24.0 \mathrm{~d}$ & $3.05 \mathrm{~d}$ & $13.2 \mathrm{e}$ & $6.06 \mathrm{e}$ \\
\hline CV $(\%)$ & 3.43 & 5.09 & 2.32 & 3.67 & 2.88 & 7.23 \\
\hline
\end{tabular}

In a column, figures bearing same letter (s) do not differ significantly at $\mathrm{P} \leq 0.05$ by DMRT

Table. IV. Effect of different mulches on soil nutrients content in onion field

\begin{tabular}{llllll}
\hline Mulching treatment & $\begin{array}{l}\text { Nitrogen } \\
(\%)\end{array}$ & $\begin{array}{l}\text { Phosphorus } \\
(\mathrm{ppm})\end{array}$ & $\begin{array}{l}\text { Potasium } \\
(\mathrm{ppm})\end{array}$ & $\begin{array}{l}\text { Sodium } \\
(\mathrm{ppm})\end{array}$ & $\begin{array}{l}\text { Calcium } \\
(\mathrm{ppm})\end{array}$ \\
\hline Black polythene & $0.097 \mathrm{a}$ & $12.52 \mathrm{a}$ & $41.02 \mathrm{a}$ & $493.2 \mathrm{a}$ & 74.81 \\
Water hyacinth & $0.089 \mathrm{ab}$ & $12.04 \mathrm{ab}$ & $42.99 \mathrm{a}$ & $471.5 \mathrm{ab}$ & 74.34 \\
White polythene & $0.088 \mathrm{ab}$ & $11.53 \mathrm{~b}$ & $37.71 \mathrm{~b}$ & $431.1 \mathrm{c}$ & 72.81 \\
Rice straw & $0.087 \mathrm{ab}$ & $10.63 \mathrm{c}$ & $34.81 \mathrm{bc}$ & $454.5 \mathrm{bc}$ & 73.53 \\
Saw dust & $0.092 \mathrm{ab}$ & $10.60 \mathrm{c}$ & $33.51 \mathrm{c}$ & $395.7 \mathrm{~d}$ & 73.10 \\
Control & $0.086 \mathrm{~b}$ & $9.59 \mathrm{~d}$ & $32.53 \mathrm{c}$ & $357.5 \mathrm{e}$ & 72.56 \\
\hline CV $(\%)$ & 3.13 & 3.64 & 5.35 & 4.77 & 3.54 \\
\hline
\end{tabular}

In a column, figures bearing same letter ( $\mathrm{s}$ ) do not differ significantly at $\mathrm{P} \leq 0.05$ by DMRT 
a greenhouse effect i. e. light energy from the sun passed through polythene to soil and is converted to heat energy under it, and then heat energy is trapped into it resulting high temperature within the polythene mulches. Mulching is known to increase soil moisture and temperature significantly within the range of $0-25 \mathrm{~cm}$ soil depth (Jamil et al., 2005) that supported the present experimental result.

\section{Effect of different mulches on morphological characters in onion}

Application of different mulches had a significant influence on morphological characters such as plant height, number of leaves and leaf length in onion (Table III). In general, plant height, leaf number and leaf length were greater in mulches plots than control plots. Among the mulches, plant height, leaf length and leaves number was higher in polythene mulches than the other natural mulches. The highest plant height, leaf length and number of leaves were recorded in back polythene. The tallest plants in black polythene compared to other mulches might be concerned with conservation of high soil moisture and temperature (Tables I and II). In contrast, the shortest plant was recorded in control plot where no mulch was used. In control plot, soil moisture was less than the other mulches that might lesser amount of nutrient availability (Table IV). As a result, plant growth and development was hampered in controlled plots (Abu-Awwad, 1999) and ultimately plants became short.

\section{Effect of mulching on growth characteristics}

The effect of different mulches on total dry mass (TDM) production in onion was significant (Fig. 1A). Result revealed that TDM increased slowly till 50 days after transplanting (DAT) followed by increased rapidly up to 80 DAT. The highest TDM production plant $^{-1}$ was recorded in black polythene mulch at all growth stages followed by water hyacinth. The lowest TDM production plant ${ }^{-1}$ was recorded in control plot where no mulch was applied. This result is in consistent with Diaz-Perez et al. (2004) who observed the higher biomass production in polythene applied plot than natural mulches in onion.

Mmulching significantly affected absolute growth rate (AGR) of onion (Fig. 1B). AGR increased with age untill 70 DAT followed by a decline with age. The higher AGR was maintained in the onion plants for the applied polythene mulches during the growth period and the lowest AGR was in control plots (without mulch). This result is consistent with the result of Gitaitis et al. (2004) who observed higher AGR in polythene applied plots than other mulches in onion. AGR is positively correlated with TDM production and LAI (Mondal
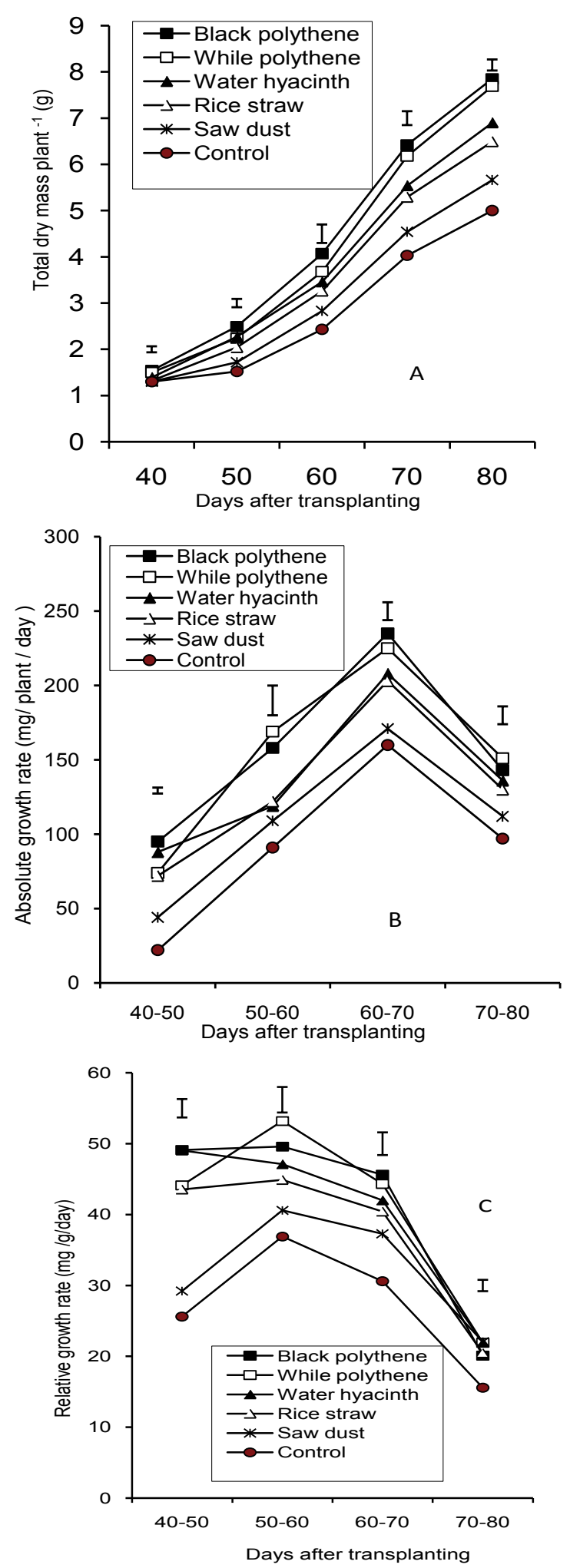

Fig. 1. Effect of different mulches on (A) total dry matter, (B) absolute growth rate and (C) relative growth rate at different growth stages in onion. Vertical bar represent LSD $(0.05)$ 
et al., 2011). The AGR increased along with increase in TDM and LAI. The lower value of AGR in control plot might be the result of lower TDM production. At 60-70 DAT, the AGR value was found to be maximum which mean that plants expanded it's assimilate for the growth of leaf area. The declining of AGR after reaching the maximum in all treatments might commensurate with slow increase of TDM.

The effect of mulches on relative growth rate (RGR) was found significant during the growth period (Fig. 1C). It was observed that an inverse relationship between RGR and plant age was existed in some treatments. RGR in three mulches showed increase in trend with age till 60 DAT followed by a decline whereas other three mulches showed decline in trend from early growth stages. Generally, with the advancement of the plant age, the RGR decreased in most of the field crops (Mondal et al., 2012). Partial similar result was also observed in the present experiment. Results revealed that Black polythene mulch generally showed superior RGR at most of the growth stages than the other mulches. RGR was higher in black and water hyacinth mulches due to production of higher TDM at all growth stages. The lowest RGR was recorded in control plot where no mulch was applied.

Effect of different mulches on yield attributes and yields in onion

The effect of mulches on yield contributing characters such as bulb diameter and single bulb weight and yield was statistically significant (Table III). Bulb diameter and single bulb weight was higher in mulched plots than the control plot. The highest bulb diameter and single bulb weight was recorded in black polythene mulch $(4.42 \mathrm{~cm}, 22 \mathrm{~g})$ followed by water hyacinth mulch $(4.12 \mathrm{~cm}, 20 \mathrm{~g})$ and white polythene $(3.85 \mathrm{~cm}, 16.5 \mathrm{~g})$. The bulb diameter and single bulb weight was higher in black polythene mulch possibly high moisture percentage compared to other mulches (Table I) which help to release available nutrients for plant uptake (Table IV) that resulted higher growth and development. In contrast, the lowest bulb diameter was recorded in control plot. In control plot, soil moisture percentage was less than the other mulches that might hamper plant growth and development resulting lower size of bulb. The highest bulb yield was recorded in black polythene mulch $\left(10.69 \mathrm{t} \mathrm{ha}^{-1}\right)$ followed by water hyacinth $\left(9.51 \mathrm{tha}^{-1}\right)$. The bulb yield was higher in black polythene mulch because of production of large size bulb. In contrast, the lowest bulb yield was recorded in control plant $\left(6.06 \mathrm{t} \mathrm{ha}^{-1}\right)$. Similar results were reported by many workers (Anisuzzaman et al., 2009; Islam et al., 2010; Rahman et al., 2013) in onion who observed that bulb yield increased due to application of mulches.

\section{Effect of mulches on soil nutrients}

The effect of different mulches on soil nutrients was significant except calcium concentration ii soil (Table IV). Result revealed that soil nutrient availability was greater in mulch plots than control plots. Among the mulches, the higher soil nutrients such as N, P, K, Na and $\mathrm{Ca}$ was recorded in black polythene and water hyacinth mulches being the highest in black polythene mulch in most of the nutrients. The lowest nutrient availability was recorded in control plot. The soil nutrients were higher in black polythene and water hyacinth mulches because of soil moisture were available there.

\section{Conclusion}

Mulching induced significant enhancement on moisture contents and temperature as well as major nutrient status in soil which enhances plant growth and development of onion. Among the mulches, black polythene mulch performed the best for getting maximum bulb yield in onion. So, it can be suggested to use black polythene mulch for increased production of onion during winter season in Bangladesh.

\section{References}

Abu-Awwad AM (1999), Irrigation water management for efficient water use in mulched onion, J. Agron. Crop Sci. 183: 1-7. DOI: org/10. 1046/ j.1439-037x.1999.00304.x

Anisuzzaman M, Asrafuzzaman M, Ismail M and Rahim MA (2009), Planting time and mulching effect on onion development and seed production, African $J$. Biotechnol. 8(3): 412-416.

Diaz-Perez JC, Randle WM, Boyhan G and Gitaitis RD (2004), Effect of mulch and irrigation system on sweet onion cultivation, J. Am. Soc. Hort. Sci. 129: 218-224.

Encyclopedia (2017), http://www.encyclopedia.com/ plantsand-animals/plants/onions.

FAO (2013), Crop Water Information: Onion. http://www. fao.org/nr/water/cropinfo onions.

FAO (2016), Production Year Book, Food and Agriculture Organization (FAO), Rome, Italy. www.fao.org/ statistics/en

Gitaitis RD, Walcott RR, Sanders HF and Diaz-Perez JC (2004), Effects of mulch and irrigation system on sweet onion, J. Am. Soc. Hort. Sci. 129: 225-230. 
Hunt R (1978), Plant growth analysis studies in biology, Edward Arnold Ltd., London, p 67

Hunter AH (1984), Soil Fertility Analytical Service in Bangladesh: A consultancy report of 1984, Bangladesh Agricultural Research Council, Dhaka, Bangladesh, p 49

Inusah BIY, Wiredu AN, Yirzagla J, Mawunya $\mathrm{M}$ and Haruna M (2013), Effects of different mulches on the yield and productivity of drip irrigated onions under tropical conditions, Int. J. Adv. Agric. Res. 1: 133-140.

Islam MN, Ahmed SU, Hossain MM and Chowdhury S (2002), Effect of mulch and bulb size on growth of onion, Pakistan J. Biol. Sci. 5: 648-650.

Islam KS, Miah MHA and Ahmed SU (2010), Effect of mulch and different levels of $\mathrm{n}$ and $\mathrm{k}$ on the growth and yield of onion, Progress. Agric. 21: 39-46. DOI: org/10.3329/pa.v21i1-2.16747

Jamil M, Munir M, Qasim M, Jalal B and Rehman K (2005), Effect of different types of mulches and their duration on the growth and yield of garlic, Intl. J. Agric. Biol. 7(4): 588-591.

Mahajan G, Sharda R, Kumar A and Singh KG (2007), Effect of plastic mulch on economizing irrigation water and weed control in baby corn sown by different methods, African J. Agric. Res. 2: 19-26.

MOA (2016), Statistical Yearbook of Agricultural of Bangladesh. Statistics Division, Ministry of Agriculture, Govt. of the Peoples Republic of Bangladesh, Dhaka, p 119. DOI: org/ 10.1016/ j.rse.2005.10.004
Mondal MMA, Fakir MSA, Islam MN and Samad MA (2011), Physiology of seed yield in mungbean: growth and dry matter production, Bangladesh J. Bot. 40: 133-138.

Mondal MMA, Puteh AB, Malek MA, Ismail MR, Rafii MY and Latif MA (2012), Seed yield in relation to growth and developmental aspects of mungbean, The Scien. World J DOI: 10.1100/2012/425168.

Rahman MA, Mahmud JA and Islam MM (2013), Influence of mulching on the growth and yield of onion, Tech. $J$. Engin. Appl. Sci. 3(24): 3497-3501.

Rhee KM, Yoon JH and Park JK (1990), Effect of polythene film mulching on the changes of soil chemical properties during the sesame cropping season, Res. Rep. Rur. Adm., soil Fert. Abstr. 54: 116-27.

Stowell B (2000), Organic kiwifruit production-maintaining soil fertility and yields, Kiwi fruit 139: 18-21.

Streck NA, Schneider FM, Buriol GA and Heldwein AB (1995), Effect of polyethylene mulches on soil temperature and tomato yield in plastic greenhouse, Scientia Agricola 52(3): 25-29.

Zayton AM (2007) Effect of soil-water stress on onion yield and quality in sandy soil, Misr J. Ag. Eng. 24: 141-160. 